\title{
Hegyesi Gábor: Emlékek a szociális munka születésének társadalomtörténetéről
}

Üdvözlöm a leendő kollégákat, akik most vagy száz év múlva esetleg elolvassák ezt a beszélgetést, mert érdeklődnek a mostani, esetleg a száz évvel ezelötti szakmai történések iránt. Nagy dolog lenne, ha a szociális munka az örökkévalóságnak is tudna érvényeset mondani!

Én úgy készülhettem erre a beszélgetésre, hogy szerencsére olyan régen születtem, hogy ott lehettem, amikor egy szakma elkezdte magát kitalálni, mert az lényegében egybeesett a munkába állásommal. A készülés során szembesültem azzal, hogy az egyik legfontosabb kollégám, Gondos Panni pont tíz éve halt meg, 2003. február 11-én. ${ }^{1}$

Meg szeretnék róla is emlékezni, mert nagyon fontos, hogy legyen a szakmának emlékezete erről a nagyon fontos és nagyon kedves emberről. Panni része lesz az elbeszélésemnek.

Igyekeztem összeszedni néhány felismerést, amiket egy generációnak meg kellett fogalmaznia ahhoz, hogy amit végzünk, azt szakmának nevezhessük. A mostani interjúban ezek közül néhány olyan összefüggésre, körülményre igyekszem koncentrálni, s azokat elmondani és elemezni, amelyek szélesebb történelmi - politikai - társadalmi perspektívában mutatják meg a szakma kialakulását, és az azt gátló, illetve segítő tényezőket - de amelyek egyben saját életem történésein keresztül elemezhetők, vagyis saját élmények is.

A szakma történetéből nyilván pontosan tudja a Tisztelt Olvasó, hogy az újabb kori szociális személyes szolgáltatások rendszerének, vagyis a szociális munka professzionális kialakításának a megindulása a nevelési tanácsadók megalapításával kezdődött 1968 körül nem véletlenül! Itt utalnék arra a társadalomtörténeti összefüggésre, hogy Magyarország egy különös színfoltot jelentett Közép-Kelet-Európában, a nagy szovjet birodalom államszocialista rendszerében. Minden országnak megvolt a maga sajátos története, minden ország a maga sajátosságai keretében próbált valamit elérni a szovjet birodalom keretében, az ott élők szempontjából jobban vagy rosszabbul.

Visszamenőleg azt elemezve, hogy Magyarország miért lett a „legvidámabb barakk”, a történet lényegében ötvenhattal kezdődik. Az ezt megelőző Rákosi-korszak fennen hirdette, hogy a szocializmusban nem lehetnek szociális problémák - ezért meg is szüntette a szociálpolitikával foglalkozó Népjóléti Minisztériumot és a civil szervezeteket, amelyek jelentős része szociális területen tevékenykedett -, mivel a társadalmi struktúrába épített rendszerek (pl. a teljes foglalkoztatás, a majd néhány év alatt teljessé váló társadalombiztosítás, az áruk és szolgáltatások árának nagy fokú állami támogatása, az

\footnotetext{
${ }^{1}$ A szöveg alapjául szolgáló szociális munka élettörténeti interjút Bányai Emőke készítette. Nemcsak az a sajátossága ennek a szövegnek, hogy egy már 2013-ban készült interjú az alapja, hanem az is, hogy szerkesztői kérésre megmaradt interjúnak, s a szövegen csak értelemzavaró esetekben változtattam. Így megörizte annak sok olyan formai jegyét, ami egy szigorúan szerkesztett szövegben biztosan nem maradt volna ebben a formában. Jól látszik a beszélt és az írott nyelv eltérése, de saját magamnak is jó tükör - túl sokat akarok elmondani egy mondatban, szabad asszociációk mentén meg-megszakad a történet, s ami a legrosszabb, van úgy, hogy soha nem tér oda vissza. Bocsássa meg nekem a kedves olvasó, hogy évek múltán mégis hozzájárultam a megjelenéshez - amin pedig sokat meditáltam - és esetleg vegye úgy, hogy egymással beszélgettünk!
} 
alapszükségletek tervezett kielégítése) megakadályozzák a szociális problémák kialakulását. Ez elméletileg egy szép konstrukció volt. Még azt is lehet mondani, hogy ez - a sztálinizmus büneit kivéve - szerethető is lett volna, bár nem teljesült soha. 1963, a nagy politikai amnesztia és konszolidáció kezdete után indul el egy sajátos kettősségpolitika. Ez azt jelentette, hogy ennek a rendszert legitimizáló, szociális problémáktól mentes, hamisan idealizált világnak, vagyis az ideológiának a hangsúlyozása megmaradt, de lassan-lassan a rendszer titokban kezdett a valósággal szembenézni. A szavak szintjén tehát nem voltak szociális problémák, de már 1963-ban elkezdődik egy szociális rendszer kiépítése, ami a valóságban létező szociális problémákra kívánt reflektálni, anélkül, hogy elismerte volna ezek létezését.

Az első ilyen „elismert” szociális probléma az óriási méretü alkoholizmus volt. Nem értette ugyanis a politikai vezetés, hogy miközben szavakban a munkásosztályé a hatalom, mégis miért piálnak a munkások, mint a kefekötő? Itt hadd nyissak egy zárójelet. Ismerik-e a kedves olvasók Haraszti Miklós nagyszerü könyvét, a Darabbért? Ö elment munkásnak egy magyar gyárba, és hihetetlen leleplező képet adott az akkori viszonyokról. Bemutatta a munkásosztálynak azt a furcsa pozícióját, hogy olyan, mintha birtokolná a hatalmat, de közben ez nem volt igaz, hiszen ugyanolyan rossz helyzetben volt, mint majdnem mindenki más. Ennek a felismerésekor kezd kiépülni az alkoholelvonó rendszer és a rá épülö klubok hálózata. Kemény politikai megfontolásból elkezdődik tehát az első elismert szociális probléma kezelése. Az is nagyon fontos, hogy betegségnek tekintik. Nem erkölcsi kérdésként, nem kriminális kérdésként, hanem az egészségügyi rendszerrel megközelíthető problémaként kezelik. Három hétre be lehetett utalni az embereket alkoholelvonó kúrára, kórházba. Igaz, hogy ezt hatósági döntés előzte meg, tehát a döntés kötelező volt. Ha például egy rendör, egy szomszéd, egy családtag bement a kerületi tanácshoz, az egészségügyi osztályra, ahol bejelentette, hogy mondjuk, a férje állandóan iszik, veri, hangoskodik, erőszakoskodik a gyerekeivel, várhatóan kötelező elvonó határozatot hoztak. (1974-ben, a III. kerületi Nevelési Tanácsadóban a legelső esetem egy általam is kötelezettségre javasolt alkoholista volt, aki a család nem megfelelő felkészítése miatt, hazatérte után, felakasztotta magát. Haláláért magamat is súlyosan okoltam, s ennek a tragédiának komoly szerepe volt abban, hogy kerestem a lehetőséget a szakma megtanulására. Ennek szerencsés kimenetele volt aztán az ausztrál ösztöndíjam 1985-87 között, s egy szociális munka MA-fokozat megszerzése. Soha többé nem vesztettem el klienst!) Különbözö kórházakban, pszichiátriai osztályokon belül hoztak létre alkoholgondozókat. Goldschmidt Dénes is egy ilyen osztályon dolgozott, Holzberger Mária is, Levendel László is. Sajnos, már nem él egyikük sem, de kell őket ismerni, mert ők állócsillagok a szociális szakma, a szenvedélybetegségek gyógyítása és az egészségügy fejlődésében. (Ez akkor is igaz, ha Goldschmidt Dénesről, sajnos nem túl dicső dolgok is kiderültek néhány éve.)

A gyógyulás fenntartása érdekében megalakult alkoholgondozó klubok a magyar nonprofit, civil szektor újjászületésének is kezdete. Magam is alapítottam egyet Menta klub néven 1974ben Óbudán, ahová bejöttek ezek a 3 hetes kórházi kezelés után gyógyuló alkoholbetegek. Azt próbáltam meg elérni, hogy ez egy anonim alkoholisták klubja legyen, név nélküli részvétellel, de akkor ezt nem engedték. Személyi igazolvány kellett, „tessék beírni a klubtagok adatait" - szólt a verdikt! Ez egy paradigmatikus jelenség volt. Mi ezen a klubon belül azonban teljesen civilek voltunk, tegeződtünk egymással. Aztán a kerületi föorvos asszony feljelentett engem, mondván, hogy túl jóban vagyok a piásokkal. Engem kirúgtak, ö maradt a vezető, de egy hét múlva egy ember nem volt a klubban. (Nem tagadom, némi 
elégtételt éreztem, de nem örültem ennek, sőt!) Nálunk, Óbudán a klub így nem maradt meg, de az ország tele lett ilyen alkoholista klubokkal. Olyan klubvezető emberek tüntek fel - igazi archetípusai a szociális munkásoknak -, akik össze tudtak hozni családokat, rendezni sorsokat, s a klubok pont úgy müködtek, mint egy normális civil egyesület. A klubok ilyen nagy számban egészen '89-'90-ig müködtek. Ha ma körülnézünk, ez már nincs egészen így, de megmaradt néhány túlélő AE (Alkoholellenes) Klub, de megalakultak a régen hiányolt AA klubok, tehát az anonim alkoholisták klubjai.

Tehát a politikai rendszer feszegetése itt kezdődött, szociális területen a valóság és az ideák szembesítésével. S folytatódott hatvannyolccal, ami a legfontosabb modern reformkorszak Magyarországon, az új gazdasági mechanizmus kezdete. Ez volt a „legvidámabb barakk” elnevezés alapja, mert ez az 1968. január 1-én bevezetett rendszer nem más, mint egy korlátozott piacgazdaság, a maga életszínvonal-növelö következményeivel. Ha ennek kiteljesedett formáját keressük, akkor azt a mai Kínában találjuk meg, ahol az egypártrendszer körülményei közepette szabad piacgazdaság müködik. Oda úgy jutott el a magyar gazdasági modell, hogy Mao Ce-tung bukása után, 1977-ben Magyarországra látogatott egy hatalmas kínai delegáció az új gazdasági mechanizmus tanulmányozása céljából. A kínaiak ezt vették át, ami lényegében egy hatalmas kompromisszum. Addig mi nem jutottunk el, mint a kínaiak, mert a piac állami piacot jelentett, tehát nem magánosították a vállalatokat. Magyarországon az állami vállalatokat helyezték piaci körülmények közé, ezzel a gazdasági rendszer meg akarta haladni a sztálinista tervgazdálkodást. Korábban a tervhivatal pontosan megmondta, hogy pl. hány kiló televíziót kell gyártani, és milyen színben - ugye nem csoda, ha 50 kilós televíziót gyártottak a Szovjetunióban, mert akkor gyorsabban megvolt az éves terv, de azokat nem is lehetett használni semmire. Eladható termékek gyártása - ez volt az a központi cél, amit a magyar reform el akart érni. Rá akarta a politikai vezetés kényszeríteni a magyar vállalatokat eladható termékek gyártására. Ma annyira egyszerünek tünik a piac müködése: kereslet és kínálat szabályozza a termelést! Az 1968 előtti magyar szocializmusban nem volt kereslet meg kínálat, mert nem volt piac. Ez volt az új gazdasági mechanizmus lényege: az igazgatóknak ki kellett találni valamilyen módon, hogy a vállalatuk hogyan gyártson pl. olyan televíziót, amit az emberek mégiscsak megvesznek. Ezután nem azt mondta meg a tervhivatal, hogy hány kiló és milyen színű televíziót kell gyártani, hanem azt, hogy hány százalék raktárkészletet lehet adott év december 31-én birtokolni. Ha alacsony a raktárkészlet, és ettől függ a vezetőség jutalma, akkor ezt a helyzetet elő kellett állítani. Vagy az árut kellett eladni, vagy az árukészletet. Mind a kettőre volt példa. Januárban, amikor a vállalatok raktárkészletét mérték, akkor Magyarország tele volt vonatokkal, amelyek mentek a gyárak között és cserélték a raktárkészletet. A magyar trükközésnek nincs határa! A vonatoknak viszont volt kapacitáskorlátja. Ezek a szerencsétlen igazgató elvtársak helyzetbe lettek hozva, mert addig nekik csak megbízható elvtársaknak kellett lenniük. Kádárnak az volt a nagy leleménye, hogy amellett, hogy az igazgató elvtársnak párthünek kellett lennie, mostantól értenie is kellett a dologhoz. Vagyis tanulniuk kellett. Így erősödött fel az a társadalmi mozgás, aminek alapján 1970-ben Szelényi Iván és Konrád György megírhatták Az értelmiség útja az osztályhatalomhoz c. könyvüket. Ezért küldték el őket Magyarországról. Visszatérve a „vonatozás"-kérdéshez: ahhoz, hogy olyat gyártsanak a gyárak, amit el lehet adni, ahhoz bizony be kellett hozni a marketinget, be kellett hozni a vállalati tervezést, mert meg kellett tanulniuk valamilyen módon érzékelni a piacot, a keresletet.

S megtörténik a nyugatra nyitás is, vagyis a nyugati piacra is elkezdtünk termelni. S elkezdtük érezni a szabadságot, ami onnan jött. Mert mi nem voltunk szabadok. Csak két, egészen apró, 
személyes példa. Mikor én az első farmert felvettem és szakállt növesztettem, akkor úgy éreztem, hogy kinyílt a világ. Ez hatvanhétben történt, rögtön az érettségim után. Átsétáltam a Margit hídon, s rögtön letartóztatott a rendör. Elkérte a személyimet, nem volt benne a szakállas kép, azonnal bevittek a rendörségre. Vagy amikor hatvannyolcban mentünk Lengyelországba - akkor már éppen elfoglaltuk Csehszlovákiát baráti segítségként -, és joggal voltak dühösek a csehek, így a határör ledobott a vonatról, mert az útlevelemben sem volt szakállas kép. Azt mondta, hogy vagy leszállok, vagy bemegyek a mosdóba és lenyírom magamról, öt nem érdekli, hogy hogyan. Ezek kis jelenetek, amik mind bevilágítanak a rendszer müködésmódjába. Összefoglalva: az új mechanizmus elvezette az országot a „legvidámabb barakk” állapotáig, s ez előkészítette azt is, hogy Magyarországon először lett piacgazdaság 1989-ben, a rendszerváltás után. Hiszen volt húsz évünk, ami alatt a magyar vállalkozók erre valamilyen módon rákészültek, mert megtanulták annak (ugyan torz, de mégis piacszerü) működésmódját.

Ennek a problémáinak az elemzésébe azonban most nem mennék bele, inkább visszakanyarodnék ' 68 -hoz, amikor megtörténik a második szociális reformlépés, a nevelési tanácsadók bevezetése. Ennek is politikai oka volt, ahogyan az alkoholgondozó központok megszervezésének. Nos, 1968-ban vált fontossá egy másik csoport, aminek ugyanilyen fontos problémái voltak, mint a munkásoknak, s ez az ifjúság volt. De milyen bajuk lehetett a fiataloknak abban az államban, ahol elvileg „nincsenek problémák”, mi lehetett a gondjuk? Emlékeznek-e Cseh Tamás dalára: „A hatvanas években tetőpontra hágott az ifjúsági probléma...”? Ez az egy mondat is mélyen bevilágít a dolgok lényegébe. Hiszen minden ifjúsági generáció lázad. A papája ellen, a mamája ellen, az iskola ellen. Nagyon helyes. Mert az ifjúság pozíciójánál fogva már elég okos, hogy meg tudja fogalmazni a problémáit, de még nem fél, mert általában nincsenek olyan kötelezettségei, gyerekei, családja, munkahelye, amiket féltenie kellene. Mit veszíthet el? Mint tudjuk, „a láncait”. Ez az életérzés az ifjúsághoz kötődik, mióta világ a világ. Az ifjúság pozíciójánál fogva nem bírja el a nemet, a tiltást. A hatvanas évek az az időszak, amikor Magyarországon is kinyílik egy kicsit a világ. Készülünk az új gazdasági mechanizmusra. (Társadalmi reformra nyíltan csak a cseh reformmozgalom készült, de azért a levegőben volt a szabadság illata). Kinyitják a börtönöket, és hatvanháromban kiengedik azokat az értelmiségieket, akiket hála istennek nem végeztek ki az ötvennyolcas perekben. Nemcsak értelmiségieket, munkásokat is, vagy akik nem csináltak semmit, csak ott voltak, vagy egyetértettek, vagy eltettek egy újságot a könyvespolcra, amelyben Nagy Imre éppen bejelent valamit. Van egy fantasztikus boldogság, egy olyan hangulat, hogy végre ezen a rémálmon túl vagyunk. Van egy közhangulat, hogy valami új lesz. Ebben az újban az ifjúság persze részt vesz, és igyekszik feszíteni a határokat. Például farmert akar hordani, és szakállt akar növeszteni - nem csak Kelet-Európában. Az egész világon! Látták a Nagy zabálás címủ filmet? Ez egy kultikus film volt, ami a fogyasztói társadalom aranykora ellen szólt, s amiben a szó szerint „halálra zabálják” magukat a film jómódú fôszereplöi. Míg Kelet-Európában, Magyarországon szegénységproblémáink voltak, a világ fejlettebb részén a második világháború után egy hihetetlen aranykor van. Amerikában ekkor zajlik a harc a szegénység ellen. Megint nagy neveket mondok: John F. Kennedy és Johnson elnökök vastag könyvekben írják le, hogy céljuk a „Harc a szegénység ellen”. Felteszik azt a kérdést, hogy hogyan lehet az, hogy Amerikában, a világ leggazdagabb országában, a hatvanas években még mindig 12 százaléknyi szegénység van? Kell valamit 
tenni ellene. Az említett Demokrata Párthoz tartozó elnökök felvállalják, majd később Clinton és Obama folytatják - ez zajlik most az egészségügyi biztosítással. ${ }^{2}$

Visszatérve a hatvanas évekre, nemcsak a zabálás, nemcsak a fogyasztás a fontos, hanem az igazi emberi értékek kerülnek előtérbe - a hippimozgalmakra utalok. Az ifjúság azt mondja, hogy nem kell a drága autó, nem kellenek atyáink céljai, hogy minél többet fogyasszunk, hanem az kell, hogy minél boldogabbak legyünk. Ne fogyasszunk sokat, éljünk közösségekben! A fogyasztás ugyanis elidegenít - mondják. Egyedül bemegyek a közértbe, megveszem a sok cuccot, és én egyedül megeszem. Ne együk! Jöjjünk össze kommunákba, és szeressük egymást. Ez a Hair címü másik kultikus film világa, amit remélem, mindenki látott (és száz év múlva is látni fognak)! S ez a világérzés megérinti a magyar ifjúságot is, mert ahogy egy kicsit szabadabbak vagyunk, hallgatjuk az egyébként tilos, de már le nem állítható Szabad Európát, farmert próbálunk, szakáll, hosszú haj, és Bereményi Géza és Cseh Tamás írják a dalaikat.

És ekkor a Politikai Bizottság ülésén a legmagasabb szintű politikai vezetők azt tárgyalják, hogy miért hordanak hosszú hajat a fiatalok, miért kell nekik a farmer. Ez azt jelenti, hogy az ifjúsági probléma - Cseh Tamás szavaival - politikai szintet ér el. Más szocialista országokban ekkor még elviszik a fiatalokat, akik farmert hordanak, mert tilos a viselésük. Ezért vittük a farmert a Szovjetunióba, és annyi pénzt kaptunk érte, hogy valami hihetetlen mennyiségü cuccot tudtunk belöle vásárolni, mert ott egyáltalán nem lehetett farmert kapni. Hoztuk a minitelevíziót (ez már nem volt olyan súlyos!), meg a kegytárgyakat. Magyarországra ikonok tömege került be farmerért cserébe. Ott bezárták a templomokat, széthordták a kegytárgyakat, amik aztán nagyon fontos valutát jelentettek. Így müködött másodszinten a kelet-európai valóság. Míg más országban büntették, Magyarországon Kádár azt mondta, hogy ha valaki farmert hord, szakálla van és hosszú haja, az nem politikai kérdés. Ez a divat, ilyenek a fiatalok, mi is lázadtunk. Ez fontos volt. Hiszen az egypártrendszerekben a helyi szintek utánozzák a központot. Bárhol akad egy párttitkár, aki túllihegi az elvárásokat. Az emberek félnek, nehogy valami olyat csináljanak, amiért később valaki összevonja a szemöldökét. A centralizált rendszerek így müködnek. Kádár azt mondta, hogy nem kell büntetni a fiatalokat - ez a lenti szinteken is védte őket. Ez nagyon jó volt, de még fontosabb - a témánk szempontjából, hogy azt is mondta Kádár, hogy valamit tennünk kell, hogy a fiatalok átérezzék, hogy ez az ő rendszerük. Sokan, sokat szenvedtek érte, maga Kádár is ült börtönben, öt Rákosi börtönözte be. Nem végezték ki, mint Rajkot, de az „elvtársak” rendesen végezték ki egymást is. Ez volt a sztálinista rendszer logikája. Kádár János ezzel is szakítani igyekezett 1963 után, és meg akarta reformálni az egész szocialista rendszert.

Az egyik az iskolareform volt 1963-ban. Én éppen abban az évben kezdtem el a gimnáziumot. Akkor még nem tudtam, de ez egy sorsfordító helyzet volt, hogy az iskolareform első gimnáziumi osztályába jártam, ezért sokkal jobb iskolát kezdtem el, mintha csak egy évvel korábban kezdtem volna. Akik hatvankettőben kezdtek, azok egy sztálinista gimnáziumot kezdtek el. Hatvanháromtól reformiskola volt. Pszichológiát és esztétikát is tanultunk, két olyan tárgyat, ami addig tiltott imperialista áltudománynak számított. A szociológiával és a kibernetikával együtt ezek megint a szabadság szimbólumai voltak. Akkor én erről nem tudtam, csak utólag értettem meg, hogy milyen szerencsém volt, hogy éppen belekerültem ebbe a reformhullámba. (Ez egyébként 8 napnak volt köszönhetö, vagyis annak, hogy az 1948. szeptember 8-i születési dátumom miatt egy évvel később kezdhettem csak el az általános iskolát.)

\footnotetext{
${ }^{2}$ Az interjú készítésének idejében, 2013-ban.
} 
Tovább folytatva a kádári vezetés elemzését, valószínüleg számított az is, hogy bár neki nem volt gyereke, de tudta, hogy ki kell találni valamit, hogy a fiataloknak vonzó legyen a rendszer, és a problémáikkal valahol foglalkozzanak. Így lettek a nevelési tanácsadók. Ez politikai döntés volt, mi szerint kell valamilyen intézményes megoldást kitalálni, ami szakmai - és nem politikai - alapon tud segíteni a gyerekeknek, fiataloknak, a szülöknek és a tanároknak. A másik, fiatalokra vonatkozó politikai próbálkozás volt a KISZ, s annak reformja, hogy mit csináljon ebben az új helyzetben, de arról itt most nem beszélek.

Most szeretnék néhány olyan példát mondani, amelyek megmutatják a nevelési tanácsadók akkori életét. Amikor már családgondozóként dolgoztam a III. kerületi Nevelési Tanácsadóban 1974-től, akkor ezt pedagógiai szakmaként képzelték el, tehát nem szociális, hanem tanári szakmaként. Nekem volt egy közgazdasági egyetemi diplomám, egy szociológia doktorim, de nem voltam tanár. Vissza kellett ezért mennem az egyetemre, hogy szerezzek egy tanár diplomát is. Beiratkoztam ismét a közgazdasági egyetemre, a Közgázra, ahol volt egy úgynevezett „tanár A” szak, ami középiskolai tanári diplomát adott. Most jön egy megjegyzés, ami talán dicsekvésnek hangzik (nem annak szánom), de nagyon büszke vagyok rá: a csoporttársak engem választottak a legjobb tanárjelöltnek. Azért mondom csak el, mert ennek fényében kell megérteni a zárótanításomat, ami a Wesselényi utcai közgazdasági szakközépiskolában zajlott. Ott voltunk tanítási gyakorlaton fél évig. A zárótanításon egy vállalatot kellett bemutatni, hogy hogyan müködik. Nagyon érdekelt a dolog, ez eléggé szociológiai téma, én pedig beszéltem, beszéltem, beszéltem - a végén a hallgatók megtapsoltak. Értékelésnél a tanár a következőket mondta: „Hegyesi elvtárs, gratulálok, nagyon jó tanári teljesítmény volt, minden didaktikai elvárásnak megfelelt, fel volt építve az óra, jól tudta mozgatni a hallgatókat, jó volt a hangulat. Egy nagyon fontos ponton azonban kritizálni kell: alig beszélt a vállalati pártbizottság szerepéröl, ezért négyes." Erre a kritikára akár büszke is lehetnék, de dühös voltam és csak megerösített abban, hogy ez nem kóser, ami itt zajlik Magyarországon. Egy csomó dolog változik és alakul, kivéve az egypártrendszert. Sokan vágytunk a demokratizálásra, de a prágai tavasz leverése után pár évvel ez akkor szinte lehetetlennek látszott.

Megint egy újabb kis történet. A reformok úgy zajlottak, hogy a párton belül mindig nagy belső harcok folytak. A párton belül két irányzat harcolt egymással, szinte a kezdetektől. Volt egy balos, moszkovita, amelyik pont azt akarta csinálni, amit Moszkvában mondtak, és volt egy reformpárti rész. Kádár valahol középen állt, s egyensúlyozott ebben a folyamatos küzdelemben. Jó érzékkel tudta, hogy mikor kell váltani, mert érzékelte a korábbi reformellenreform hullámzást is. Az első nagy hullám az '53-ban volt - hogy még tágabb kontextusba helyezzem a kérdést -, vagyis az első nagy reform az volt, amikor Nagy Imre megszüntette a kötelező beszolgáltatást. Ezért lett Nagy Imre olyan népszerü, ezért fogadták el a forradalom miniszterelnökeként. Egy emberként mögötte állt Magyarország, mert azt mondta '53-ban, hogy nincs többé padláslesöprés. Ez volt az első reform, ami kudarccal végződött, mert Nagy Imrét félretették, Rákosi visszajött. Majd kitört az 1956-os forradalom, a második reformkísérlet, de az is elbukik. Utána jön '63, a konszolidáció és a gazdasági reform előkészítésének meghirdetése. Ez tart 1970-ig, amikor Kádár János kiteszi a vezetésből az új gazdaságireform-mechanizmust előkészítő embereket, és visszakerülnek a konzervatív „moszkoviták”.

A nevelési tanácsadó rendszer létrehozása tehát nem önmagában áll, hanem a korszak szelleméből következik. Amikor reformidőszak van, akkor a párton belüli reformerők 
szövetséget kötnek a párton kívüli reformemberekkel, akik a rendszert alapvetően elfogadják, és javítani szeretnék. Baloldaliak, akik balról kritizáltak abból a szempontból, hogy a rendszer nem valósítja meg a céljait. Vagyis felrótták a rendszer vezetőinek, hogy a humanisztikus, emberi teljességet ígérő rendszer nem foglalkozik olyan problémákkal, mint hogy gyerekek elmenekülnek otthonról, hogy családi botrányok, verekedések vannak, a gyerekek boldogtalanok és néhányan öngyilkosok lesznek stb. - s ezekre a rendszernek nincs válasza. Pedig ez elvárható lenne egy olyan rendszerben, ami céljai szerint humanizáló, nem kizsákmányoló, s már húsz éve van hatalmon, vagyis ezek a fiatalok már ebben a rendszerben születtek és nöttek fel. A párton belüli és a párton kívüli reformerek összefogtak tehát, és olyan eljárásokat javasoltak, amelyek pl. a fent említett problémákat megoldják, illetve szakmai eszközökkel kezelni tudják. Hadd nevezzek meg néhány embert, akik ebben párton belülről, illetve párton kívülről közremüködtek. A párton belül Nyers Rezső, Aczél György és köre, a párton kívül pedig egy hozzánk nagyon közelálló intézmény, a Bárczi Gusztáv Gyógypedagógiai Főiskola egyes oktatói, akik jelentős szerepet játszottak a '70-es évek elején megalapított tanszék, illetve képzés elindításában. Ilyen volt a föiskola akkori igazgatója, Göllesz Viktor, aki 1972-ben elindítja a szociális munka elődjének számító szociális szervezö képzést, amit aztán Kemény Ferenc és Szabó Lajos neve fémjelez. S ott dolgozott az 1973ban elindult pszichopedagógia szak megalapítója, Murányi-Kovács Endréné (akit majd Aczél Anna és Volentics Anna követnek), aki szakmájánál fogva járt Párizs tizenharmadik kerületében, ahol a nevelési tanácsadót kitalálták. Ez egy iskolapszichológusi hálózat - most csak összefoglalva mondom -, melynek az a koncepciója, hogy a gyerekeket in situ az iskolában, tanulás közben kell támogatni, akár a tanárral van baja, akár a többi gyerekkel, mert ugratják például, akár azért, mert a fejlödésében olyan zökkenök vannak, amikkel nem tud megbirkózni. Például gyerekkorában traumatizálódott, mert háromévesen jelen volt, amikor a nagymamája meghalt stb. Itt szakmai eszközökkel kell segíteni a gyógyulást. Ez a szakmai javaslat a nevelési hálózatok megalapítása, s ez kerül a Politikai Bizottság elé. Döntés születik, hogy az akkor már létező ifjúságsegítő tanárokból, meg az újonnan engedélyezett pszichológusokból - akik már tanulták a szakmájukat, mielőtt azt betiltották volna - létre kell hozni ezt a hálózatot, kompromisszumos formában. A kompromisszum úgy szólt, hogy nem iskolapszichológusi hálózatot hoztak létre, hanem területi központokat, ahol azonban minden iskolának lesz egy felelös pszichológusa. Nyilván nem minden iskolának külön, hanem mondjuk háromnak egy. Ezekben a nevelési tanácsadókban adott esetben még orvos, pszichiáter, fejlesztő pedagógus, gyógypedagógus dolgozik. Ez '68, ekkor kezdődik a nevelési tanácsadók kiépítése. Az volt az elképzelés, hogy 30-35 000 emberre jut egy nevelési tanácsadó. Ez Budapesten egy kicsit másképp alakul, mert lényegében kerületenként volt egy, de volt olyan kerület is - például Óbuda -, ahol kettő volt, egy Békásmegyeren, egy pedig Belső-Óbudán. De vidéken úgy telepítették a nevelési tanácsadókat, hogy körülbelül ennyi emberre jusson egy. A csúcsponton - már később, a nyolcvanas években - 156 nevelési tanácsadó volt Magyarországon. A reform tehát létrehozza az ifjúsággal foglalkozó szociális, pedagógiai intézményt. Maga a reformkorszak véget ér '70-ben, amikor Kádár János elfordul a moszkoviták felé, megmerevedik a rendszer, megszünnek a reformgondolatok és egy kicsit olyan lesz az ország, mint a Szovjetunió maga Brezsnyev idején, tespedt minden és unalmas. De megint teszek egy jó pontot a Kádár-életrajz mellé: nem vonja vissza a reformdöntéseket. Sem a gazdasági mechanizmust nem vonja vissza, csak lassítja, se a nevelési tanácsadókat, se az alkoholgondozókat. Jönnek vissza a moszkovita politikusok a legfelsőbb vezetésbe, de megmaradnak az alapvető reformeredmények. Azért kerülnek vissza a moszkoviták, mert az ötven legnagyobb vállalat vezetői, ahol a munkásság legnagyobb része dolgozik, nehezen 
állnak át az új rendszerre, s nem nagyon értik, hogy hogyan lehet olyat termelni a tervhivatal segítsége nélkül, amit aztán el lehet adni? Ilyen tudással ugyanis ök nem rendelkeztek, vagyis sokuk egzisztenciálisan fenyegetve érezte magát. Ezért inkább megfúrják a rendszert - most a reformellenes erők fogtak össze. Ekkor jártam a közgazdasági egyetemre 1968 és '73 között, és megtapasztalhattuk a változást: hallgathattuk a reform vezető közgazdászait 1970-ig, majd láthattuk fájdalmas háttérbe szorításukat is, s a végén a Lukács-pert 1972-ben, 10 vezető szociológus és filozófus eltiltásával és külföldre kényszerítésével.

A nevelési tanácsadók azonban nagyon szépen fejlődtek. És itt kell egy nevet említenem, akinek nagyon sok köszönhető. Ö Horányi Györgyné, Annabella, akinek soha nem múló érdeme, hogy szakfelügyelőként összefogta és fejlesztette ezt az új hálózatot. Ö maga pszichológus volt, akit kifejezetten a reformgondolkodás jellemzett. Nagyon odafigyelö, megértő és aktivizáló volt, és meg tudta védeni az egész rendszert később is, amikor romlott a világ. Annabella idejében igazi szakmai munka folyt. Egy sziget volt a nevelési tanácsadó, ami meg tudta örizni a nyitottságát a vezetés szakmaisága miatt.

1972-től pedig megjelenik egy olyan munkakör, ami számunkra a legfontosabb - ezt hívták családgondozónak. A nevelési tanácsadóban a legelején nem volt még családgondozás, de az ott dolgozó munkatársak: pszichológusok, orvosok nagyon gyorsan felismerték, hogy kétféle munkára van szükség. Az egyiket ők végzik akkor, amikor bejönnek a szülök, gyerekek a nevelési tanácsadó falai közé, leülnek egymással, s elkezdődik a szakmai munka. Ennek során fogalmazódik meg az igény egy más típusú munkára is. Jó lenne tudni ugyanis azt is, hogyan is élnek otthon, milyen a kapcsolatuk a szomszédokkal, milyenek a munkahelyi viszonyaik stb.? Hogyan fogjuk mindezt megtudni? Kellene valaki, aki mindezt összegyüjti. Így találnak rá a családgondozóra, aki elmegy a családhoz, a szomszédhoz, a munkahelyre, szakmai felhatalmazással és célokkal. Egyrészt azért, hogy információval segítse a bent dolgozókat, másrészt, hogy ő maga is segítsen a problémák oldásában egy új, kialakuló szakmában, amit akkor úgy hívtak, hogy családgondozás, ma úgy, hogy szociális munka. Itt születik a szakma a szemünk előtt. Az ősalapítók között volt Ohly Éva, aki nemrég halt meg sajnos, Almásy Judit, aki már nyugdíjban van és magam is. Budapesten a harmadik családgondozó voltam, tehát elég korán bekerültem a hálózatba. Kiváló kollegáim voltak! Tapasztalat, hogy ezek az ún. nulla generációk mindig speciálisak abból a szempontból, hogy kell egy kis kalandorság is ahhoz, hogy valaki belevágjon a nagy ismeretlenbe! Ez egy kicsit olyan, mint amikor elindulok a nagy óceánon egy vízióval (mint a felfedezők annak idején), de a fene tudja, hogy mi lesz, hogy át tudok-e érni a másik partra, és egyáltalán, hol az a másik part?

Folytatnám most már a családgondozás elemzésével. Alapvető probléma volt, hogy akkor még nem volt képzés, nekünk kellett kitalálni a szakmát. Hivatalosan valamilyen pedagógiai munka volt - nekem is ezért kellett tanárszakot végezni, amint említettem. De pillanatok alatt beláttuk, hogy ennek semmi köze a tanársághoz. Az oktatás egy normatív szakma. Nem akarok értékkülönbséget felállítani a családgondozás és az oktatás között, de a két szakma között koncepcionális eltérés van. A tanár munkájának lényege, hogy tudja, mit akar megtanítani a diákoknak, és ráadásul azt még számon is kéri és osztályozza is. Azt nézi, hogy egy tudássztenderd mennyire teljesül. A magatartás terén is normatív, mert tudja a tanár, hogy mit vár el a diákoktól. Például, csöndben kell lenni, nem szabad fecsegni, be kell járni az órára, nem szabad elkésni. Millió olyan szabály van, amit egy tanár számon kér. A szociális munkás, a családgondozó ezzel szemben mivel találkozik? Csupa problémával, amiket nem lehet normatív szabályozással megoldani! Müködik az, ha azt mondjuk, hogy (egyik első, 
saját esetemre utalva) „Horváth úr, magának le kell tenni a boros poharat, nem szabad bevonulni a gardróbba és egész este ott ücsörögni, hanem jobb lenne, ha a hálószobájukban aludna"? Rögtön rájövünk, hogy itt nem lehet normatív módon müködni. Elkezdünk együtt dolgozni a kliensünkkel, és együtt kitaláljuk azokat a célokat és módszereket, ahová a „hozott anyagból" el tudunk jutni. Horváth úrnak - mint ahogyan senkinek sem - nem tudom már kicserélni a gyerekkorát, nem tudom a feleségét se kicserélni, sőt őt sem tudom kicserélni, a gyerekét se, a munkahelyét se, a korát se tudom kicserélni. Van egy adott problémarendszer, és együtt kitaláljuk, hogy A-ból el tudunk-e jutni B-be, és azt is, hogy hogyan tudunk ezen közösen dolgozni. Vagyis bizonyos változások elérését kell és lehet közösen célként kitüzni. Persze a tanárságban is benne van a közös munkához szükséges motiváció, de a szociális munka szinte csak erről szól. Nem a normák hiányoznak, nem etikátlanságról van szó, csak annak az elérése az egy közös dolog: nem tudom én egyedül kitüzni, hogy oda megyünk, és nem tudom, mi a jó, és mi a rossz. Oda tudunk menni, ahova az illető azt mondja, hogy igen, oda én is el szeretnék jutni. Nem én tanítok, és ő jegyzetel, hanem elkezdünk gondolkodni, hogy mi a baja és szerződést kötünk a közös munkára. Akkor persze ezt nem tudtuk, gőzünk sem volt - ma úgy mondanánk - a problémamegoldó modellről. Mikor Horváth úr azt mondta, hogy „Gábor, tudom én, hogy le kellene tenni a poharat, de nem tudom letenni, mit csináljak?", akkor világos, hogy nem én döntöm el, nem a szociális munkás dolgozik a kliens helyett. Közösen dolgozunk, de a kliens munkája abszolút elkerülhetetlen. Tudunk és ismerünk, mi szociális munkások, sok mindent, szociális törvényeket, pszichológiát, kongruens kommunikációt stb., de mindez nem helyettesíti azt, hogy neki van dolga, és dolgoznia kell a saját problémáján. Én nem tudok helyette dolgozni, esetleg motiválni tudom. Nagyon sokat tanultam a Horváth családdal való munkából. Voltak jó időszakok, de mindig visszaestek. Százszázalékos siker alig van. De az biztosan nagy siker volt, hogy nem lett öngyilkos, hogy nagyobb balhék nem voltak, a verekedések megszüntek, tehát jobban éltek, mint nélkülem. Nem rólam van itt szó, hanem a szociális munka hitelességéről és lehetőségeiről. Nem értük el teljesen a célunkat, de sokat elértünk, például azt, hogy mindig készültek arra, hogy találkozunk. Nekik ez egy ünneppé vált. Később a felesége el is mondta, hogy „,[o]lyan jó arra gondolni, hogy jövünk a nevelési tanácsadóba, felöltözünk, egy kicsit mintha színházba mennénk. El kell mondanunk az életünket. Végre valakit érdekel az életünk." Erre se szoktunk gondolni, hogy a magányosság és elidegenedettség ezt okozza. Élünk, mindennap felkelünk, rohanás, reggeli balhék, akkor elmegy az ember a munkájába, amit vagy utál vagy nem utál, de ahol azért általában vannak konfliktusok, aztán hazamegy, takarítás, nincs pénz, de be kell fizetni a számlát, egymás csesztetése, kialakulnak a játszmák, pontosan tudja, hogy ha az egyik ezt mondja, akkor a másik azt fogja mondani, nem fog tudni kitörni belöle... A klienseink nagy része így él - egyébként a nem kliensek nagy része is így él -, ám nekik nincs olyan mázlijuk, hogy kapjanak egy szociális munkást. :) Mindenesetre elmondták ezek a nagyon helyes emberek, hogy nekik ez mennyire fontos, hogy időnként el tudják mondani, mi a bajuk, és utána jobb az élet.

Folytatva a fontos, szakmateremtő emberek felsorolását, hadd beszéljek Hoffmann Gertiről ${ }^{3}$. Ö volt a II. kerületi Nevelési Tanácsadó alapító igazgatója. A nevelési tanácsadók kiépítésében Horányi Annabella jobbkeze. Ök ketten együtt indulnak. Fontosak a sorsok. A szociális munka története nemcsak arról szól, hogy kell tudni, hogy a szakmában mi minden

\footnotetext{
${ }^{3}$ Figyelmébe ajánlom a T. olvasónak a Szabó Ervin Könyvtár honlapján található Szociális Szakma Digitális Arcképcsarnokát, ahol több neves szakmaalapító szakember életrajzával ismerkedhetnek meg - többek között Hoffmann Gertiével is. Ld.: www.fszek.hu/szociologia/szszda/.
} 
volt, hanem ennek a mélységét kell tudni. Bizonyos emberek előtt kalapemelés jár, érteni kell, hogy abban a kontextusban mit tettek azért, hogy ide eljussunk. Akkor sok minden nem volt még természetes, ki kellett harcolni a szakma nevében egy szakmai szintet és ebben nagyon sokat tett Gerti és Annabella. Gerti élete is nehéz volt, élete vége tragikus. 1999-ben a halált választotta egy szörnyü, gyógyíthatatlan betegség miatt. Tüdőideg-sorvadása volt, amitől megfullad az ember, szörnyü, pokoli halál, s ezt ő nem akarta megvárni, meg azt sem, hogy az előtte levő hónapok borzalmait a barátaira tegye rá. Úgy intézte, mintha elutazott volna, közben otthon gyógyszerek segítségével meghalt. Hozzá illő méltósággal!

1963-tól '69-ig volt annak a gimnáziumnak a pszichológiatanára, ahová én jártam. Nekem iszonyú szerencse, hogy így keresztezödött a sorsunk. Mindketten újpestiek vagyunk. Neki köszönhettem tulajdonképpen, hogy a pályára kerültem. Hihetetlen jó gyerekpszichológus volt, és mindenki, aki őt ismerte, egy perc alatt a hatása alá került. Ránézett az emberre és egy pillanat alatt érezni lehetett, hogy Ö jelen van. Ez nagyon fontos a szakmában! A következő dolog, amit tanultam Töle, hogy nem lehet, de nem is kell minden klienst szeretni, de mindenkit tiszteletben kell tartani, és egy tisztességes szakmai kapcsolatot kell kialakítani és fenntartani. Nem a szeretetből jön a figyelem, hanem a szakmaiságból jár a figyelem, hogy ott vagyok, jelen vagyok, hogy rá figyelek. Ugyanakkor létezik egy szakmai „skizofrénia”, amit minden szociális munkás és minden pszichológus tud: ott vagyok vele, a klienssel, és együtt rezdülök vele, de közben van egy képességem, amivel kívülröl is figyelem magunkat, hogy mi is történik, és már azon gondolkodom, hogy hogyan tudok szakmailag továbblépni, vele együtt, természetesen. Ezt Gertiék írták le elöször. Horányi Annabella és Hoffmann Gerti könyve a nevelési tanácsadókról szól. 1988-ban írta le Gerti a Gyermek- és ifjúságvédelemben: „Hogyan látom a családgondozó szerepét a nevelési tanácsadóban?” címen. Ebben azt írja, hogy a családgondozó és a kliens kapcsolata egyszerre „,hivatalos és baráti”. Ez a paradoxon az, ami igazán kifejezi ezt a skizofrén helyzetet, mi szerint valóban közel kell kerülni egymáshoz, és éreznie kell a másiknak a megértésemet. Közel kell lenni, hogy megértsem az ő problémáját, és engedni kell, hogy hasson rám, hogy tudjak rá empatikusan rezonálni, hogy átérezzem, hogy ő mit érezhet. Ezt meg tudom akkor is csinálni, ha nem szeretem egyébként. Ez két teljesen külön dolog. De itt müködik ez a „skizofrénia”, ez a másik agy, amivel azon gondolkodom, hogy kettőnk kapcsolatában hol tartunk, mit érzek, hogyan tudok neki olyan információt adni vagy olyan kérdést feltenni, amitől a probléma tovább tud gördülni. Tehát egyszerre vagyok az ügyön belül és kívül. Ez nagyon nehéz, de enélkül nem lehet végezni szociális munkát, mint ahogy pszichológiát sem. Ez volt a következő nagy felismerés, és ennek a megfogalmazása is Gertitöl és Annabellától származik.

Litván György mondott beszédet Gerti temetésén, és Göncz Árpád is írt az emlékére megjelent könyvbe. Ugyanis vádlottak voltak a Mérei-perben, amelyben Gerti négy év és két hónapot kapott, s ebböl három évet le is ült. Együtt voltak bebörtönözve. Nem fegyveres harcosként vett részt '56-ban, hanem az '56-os forradalom meg nem valósult céljáért küzdött, együtt egy sor más értelmiségivel, akik a társadalom demokratizálását tüzték ki célul. A többpártrendszer azonban egészen 1989-ig nem jön létre, civil szervezetek nem tudnak alakulni. Ezt szerette volna Litván György, Göncz Árpád és az a kör, amiben benne volt Gerti is. A börtönévek, az általános amnesztia után éppen abban az évben, 1963-ban került a Könyves Kálmán Gimnáziumba, amikor én elkezdtem az iskolát. Így tanulhattam tőle pszichológiát - és néhány évvel később, 1974-ben az ő tanácsára kerestem meg Marót 
Miklósnét, Jucit, a III. kerületi Nevelési Tanácsadó fantasztikus vezetőjét, és elkezdtem családgondozóként dolgozni.

Azt már említettem, hogy ekkor visszamentem az első diplomámat adó Marx Károly Közgazdaságtudományi Egyetemre. Itt hadd tegyek ismét egy kis életrajzi kanyart. Eredetileg azért mentem a Közgázra, mert akkor is egy olyan szakmát szerettem volna tanulni, aminek akkor, 1968-ban még nem volt egyetemi képzése, vagyis szociológiát. Ebben nagy szerencsém volt, mert a mai nevén Rajk László Szakkollégiumban lehetőség volt tanárt választani - így négy évig Szelényi Ivántól tanulhattam. Ezzel a háttérrel vettek fel a Szövetkezeti Kutató Intézetbe egy olyan volt egyetemi társam helyére, aki férjhez ment egy Pesten élő portugál forradalmárhoz, de elment vele, amikor megbuktatták Salazar rendszerét. A „SzövKut” nagyon fontos szerepet játszott szellemi fejlődésemben, mert tele volt kitünő emberekkel, mint Talyigás Kati, akivel ott ismerkedtem meg, Juhász Pál agrárközgazdász, Földvári Tamás, Zsille Zoltán, Tellér Gyula szociológusok, Donáth Ferenc és Gyenes Antal igazgató, igazából politikusok és még sokan mások. Az intézet bizonyos értelemben egy ellenzéki gyüjtőhely volt. De csak bizonyos értelemben. Mert volt egy párttitkár is, aki vigyázott arra, hogy a belső szabadságunk ne kerüljön nyilvánosságra. Ezért már az első kutatásom, ami a húshiány okairól szólt, az asztalfiókba került, miután ezt írta rá: „Támadja a tervgazdaság koncepcióját, nem publikálható." Igazából ezért meséltem el mindezt, mert ekkor kerestem meg Hoffmann Gertit, akinek a tanácsára elmentem Marót Jucihoz.

Tehát most visszatérünk hozzá, akivel ismét óriási szerencsém volt. Ö volt Annabella és Gerti mellett a harmadik kiemelkedő személyiség a nevelési tanácsadók hálózatában. Fantasztikus vezető volt. Mellette szabály volt, hogy mindenkinek szárnyalnia kellett - szabadon és megszállottan dolgoztunk, egy csodálatos csapatban, együtt például Herpai Annával, Vekerdy Tamással, Pénzes Eszterrel, Magyar Eszterrel, Gondos Pannival, Karczag Judittal, aztán a sok-sok később jött nagyszerü fiatallal. Panni gyermekpszichológus volt, de ,átcsábítottam” családgondozónak. Öt az az újdonság izgatta, hogy míg a pszichológusokhoz bemennek a kliensek s egy védett szobában dolgoznak, úgy, hogy ők határozzák meg a feltételeket, addig nekünk ki kell menni, ismeretlen körülmények közé - és meg kellett alkotnunk egy ismeretlen szakmát, amit akkor még senki nem tudott, hogy mi az? Adott esetben a lakásban benn csattogás, röpülnek a poharak, üvöltözés van, fogalmunk sincs, mi fogad, amikor bemegyünk az ismeretlen terepre. Sokkal nagyobb a rizikó, azonnal kell reagálni. Közös „találmányaink” Pannival a szülőcsoport, amit az óbudai Nevelési Tanácsadóban együtt hoztunk létre, illetve az esetmegbeszélő csoport, amit pedig az Ör utcában, a budapesti nevelési tanácsadós családgondozóknak vezettünk együtt. Ez utóbbi egyfajta (csoportos) szupervízió volt, ami nélkül nincs szociális munka. Büszke vagyok, hogy mi ezeket anélkül találtuk ki, hogy tanultuk volna - mert, persze, ezek ismert módszerei voltak már akkor is a szociális munkának - és értékállónak bizonyultak. Mi írtuk le elöször azt is idehaza, hogy a szociális munka a dilemmák rendszere, a beavatkozási dilemmától az elkötelezettségi dilemmáig. S a szülőcsoportban kezdtük el kipróbálni az akkor külföldről frissen behozott könyvet, a PET-et, a Szülöi hatékonyságnövelő tréninget, Gordon világsikert elért módszerét, ami aztán Várkonyi Zsuzsa mesteri fordításában vált ismertté és terjedt el a magyar szakemberek körében is.

Munkánkat azonban nagyon gátolta, hogy sokféle családi szolgáltatás hiányzott, amikkel családgondozóként találkoztunk. Ezért alapítottuk meg Gondos Pannival, Gayer Anikóval és Siklaky Istvánnal 1982-ben a Lares Humánszolgáltató Kisszövetkezetet, hogy a hiányzó 
humán szolgáltatásoknak legalább egy részét nyújtani tudjuk. A Lares volt a szocializmusban az elsö, nem állami, hanem civil humán szolgáltatásokat nyújtó szervezet, ami megtörte az állami monopóliumot a szociális szolgáltatások terén, $\mathrm{s}$ egy nagyon kis lépést tett a társadalom és a szakma demokratizálásának irányába. Ezt azért tehettük meg, mert ekkor, 1981-ben engedélyezték, hogy szociális ellátást nem állami intézmény is végezhessen - ez volt a híres 1981. novemberi „piac”-törvény, ami létrehozta a kisszövetkezeteket és a gazdasági és vállalati gazdasági munkaközösségeket. Engem nem sokkal ezután rúgtak ki a Szövetkezeti Kutató Intézetböl, mivel elkezdtem pénzt gyüjteni a lengyel Szolidaritás Szakszervezet 1981 karácsonyán végrehajtott Jaruzelski puccs után elbocsátott munkanélküli embereinek. Később megtapasztaltam, hogy a legjobb jó történt velem, mert ekkor kerültem a helyemre. Végre fóállásban avval foglalkozhattam, ami a legjobban érdekelt, vagyis egyének, családok és közösségek szociális problémáinak oldásával, módszerek kipróbálásával, szakmafejlesztéssel. Legalábbis mi így éreztük, s ezt reméltük. Megalakult a Lares Óvoda vérzékeny és autista gyerekek számára Szirmay Gábor vezetésével, vállaltunk házi gondozást és ebédkihordást, gyerekfelügyeletet, beszélgetést idős, magányos emberekkel, sőt eleinte még folytattuk a Négy Évszak Társkereső Szolgálat munkáját is. Nagyon fontos humán szolgáltatás ez is!! Hetente tartottunk esetmegbeszélő csoportot, és kidolgoztuk a szolgáltatásunk etikai kódexét. A Lares, gyerekszolgáltatásokat nyújtó szervezetként, 36 év után, még ma is létezik!

Fontos volt a szakma fejlődése szempontjából egy sor más esemény is a '70-es évek végén, '80-as évek elején. 1979-ben Havas Gábor, Iványi Gábor, Lengyel Gabriella, Matolay Magdolna, Nagy András, Nagy Bálint, Pik Katalin és Solt Ottilia megalakították a SZETA-t. Dr. Gayer Anikó megalapította a Családgondozók Klubját a Pozsgay Imre által „reformosan” vezetett Népfronton belül, Almásy Judit és Ohly Éva elkezdték szerkeszteni a Családgondozók Lapját. Magam pedig - Aczél Anna meghívására - elindíthattam az első olyan választható tárgy oktatását a Bárczi Gusztáv Gyógypedagógiai Tanárképző Főiskola pszichopedagógiai képzésén belül, aminek a nevében már benne volt leendő szakmánk megnevezése: „A családgondozás mint az első szociális munka”.

Ferge Zsuzsa ugyanakkor elgondolkodtató kritikát fogalmazott meg a szociális munkával szemben - fel kellett készülnünk a válaszra! Kritikája az angol radikális feminista szociális munkások véleményére támaszkodott, akik szerint az akkori szociális munka annyit ér csak, mint egy sebtapasz, amitől esetleg nem fertőződik el a seb, de nem változtatja meg azt, amitől megsebesedett az ember. Strukturális vagy legalább csoportszintủ változások és csoportmobilizáció kívánatosak, az egyéni szociális munka pedig nem egy olyan koncepció, amit támogatni lehet, írta.

Mindezzel a háttérben indult a szempontunkból két legfontosabb kutatás az évtized elején, $A$ szociálpolitika megújítása témával foglalkozó kutatás, Ferge Zsuzsa vezetésével, illetve a Társadalmi beilleszkedési zavarok c. kutatás, Pataki Ferenc irányításával. Mi, Talyigás Katival mind a két programban részt vettünk, együttmüködve kiváló kollégák sorával, pl. Somlai Péterrel, Molnár Évával, Szalai Júliával s még sok mindenki mással. Mind a két programban, azok sajátos szempontjai mentén, azt igyekeztünk leírni és bizonyítani, hogy szükség van a szociális munka oktatásának a bevezetésére, mert a szociálpolitika rendszeréből a pénzügyi ellátás és a természetbeni szolgáltatások mellett éppen a személyes szolgáltatás hiányzott. Ebben nagyon fontos volt Ferge Zsuzsa véleménye - az imént leírt vita ismeretében. Érdekes volt az a folyamat, ahogyan közeledtünk egymáshoz. Zsuzsa egyszer 
kapott egy levelet egy klienstöl, aki leírta, hogy milyen bajai vannak a gyerekével, a férjével, s kérdezte, nem látogatná-e meg. Zsuzsa megkérdezte, hogy nem akarok-e vele menni a klienshez. Kicsit aggódott, joggal. Amikor az ajtóhoz értünk, bentről hallatszottak a balhé hangjai. Nem nagyon akart bemenni. Én azonban egy sokunk számára ismerős terepen jártam, és tudtam, hogy az emberek hogyan alkalmazkodnak a helyzethez - ráadásul a család tudta, hogy jövünk. Kopogtam, bementünk, aztán elkezdtünk beszélgetni, ami nagyon jól sikerült. Utána Zsuzsa elmondta, hogy megértette, hogy ez mégiscsak egy fontos szakma, és nem csak „sebtapasz”. El tudta fogadni, bár számára a strukturális változás lett volna a fontos, amivel magam is egyetértettem egyébként. Ma a pszichoszociális szociális munka megközelítésben ez fontos szerepet is kap, hiszen ezért tanítunk szociálpolitikát, jogi tárgyakat, szociál- és társadalompolitikát, s ezért kell prevencióban gondolkodni, és a struktúrát lehetőleg úgy változtatni, hogy a problémák ne ismétlödjenek meg. Ám az emberi problémák csak személyesen oldhatók meg, vagy legalább változtathatók. Mert ha pl. elvesztem a munkámat, az egy strukturális okkal függhet össze, de azok a sérülések, amiken átmegyek, azok egyéniek. Ha valaki már három éve munkanélküli és tökéletesen elveszti az önbizalmát, és valahogy végre munkához jut, esetleg már nem tud elmenni reggel dolgozni, mert „elfelejti”, hogy hogyan kell egy munkáséletet élni - vagy rááll egy bűnöző életformára. Mert valamit mindenkinek kell kezdeni az idővel, valami értelmet kell neki adni. Ha belesodródik egy olyan társaságba, akik betörni járnak, akkor elöbb-utóbb vagy börtönbe kerül, vagy megpróbál segítséget kérni, hogy kitörjön abból az életből, de ez csak személyesen közelíthető meg. Kelet-Magyarországon hiába biztosítanának munkahelyeket, az ott élö harmadik generációs munkanélküli, jelentős arányban cigány népesség (természetesen nem genetikai okokból) nem tudna azonnal dolgozni, mert a munkára való szocializáció hiányozna. Senki nem tudná ezt megoldani egyik napról a másikra. Ebben kötöttünk akkor szövetséget Ferge Zsuzsával: nem szabad szembeállítani a személyest meg a strukturálist, mert a kettő egybefonódik. A szociálpolitika és a szociális munka szövetsége jött ezzel létre, ami alapvetően fontos a mai napig a képzésünkben - sajnos, a gyakorlatban már kevésbé!!!

Az elözményekhez talán még hozzátartozik az a történet, ahogyan 1985-ben kaptam egy ösztöndíjat Ausztráliába, és milyen, a korra jellemző körülmények között, nagy nehézségek árán, az akkor feltünt és általam ismeretlenül megkeresett Csehák Judit SZOT-elnök önzetlen segítsége révén tudtam csak kijutni Melbourne-be, a Monash Egyetemre. Amikor már majdnem készen volt a szakdolgozatom, aminek az volt a címe, hogy „Az elmélet és gyakorlat integrációjának néhány aspektusa egy leendő magyar szociális munkás képzés szempontjából”, 1987 májusában, akkor pedig Ferge Zsuzsától kaptam egy levelet, amiben meghívott a szociális munka tárgyának az oktatására az akkor már második éve az ELTE-n folyó, általa indított, és korszakos jelentőségű szociálpolitikai képzésbe, olyan kiváló hallgatók tanárának, mint pl. Lévai Kati, Ohly Éva, Almásy Judit (akik azután barátaim, kollégáim lettek), és még sokan mások, és olyan kiváló szociális munkás kollégákkal, mint pl. Talyigás Kati, Ronald Woods, Pik Kati, Göncz Kinga, s természetesen a többi tárgy főállású és külsős oktatóival. Azóta is hálás vagyok ezért a lehetőségért, ami megváltoztatta az életemet - és remélem, megszolgáltam a bizalmat!

Amikor 1987-ben hazatértem, egy MA-val a zsebemben, kezdődött a szociálismunkás-képzés és a szociális munka nagy korszaka, Csehák Juditnak (aki ekkor már szociális és egészségügyi miniszter volt), Bánfalvi István államtitkárnak, kiemelten Ferge Zsuzsának és még sok nagyszerü kollégának köszönhetően, és nagyon boldog vagyok, hogy részese lehettem ennek. A diplomamunkámban egy víziót vázoltam fel arról, hogy milyen lenne egy magyarországi 
szociálismunkás-képzés, az „általános szociálismunkás-képzés”. Életem nagy ajándéka, hogy a Monash Egyetemen eltöltött két év és a szakdolgozatom ilyen gyorsan hasznosult, és alapját képezhette a „Soproni norma” néven 1989-ben elfogadott alaptantervnek. Hiszen a dolgozatomból tudtam átemelni a képzés általános koncepcióját, a képzésben tanított tantárgyi blokkokat, s ezen belül a szociálismunka-blokk legfontosabb elemeit, így például az elmélet és gyakorlat arányát, a gyakorlati képzés lehetséges modelljeit, a modern szociális munka által használt legfontosabb elméleteket és fogalmakat, mint pl. a problémamegoldó modell, a dilemmák feloldása, az általános és specializált szociális munka egymásra épülésének megoldásai, Abraham Flexner és a tudományos kutatás szerepe a szociális munkában stb. $\mathrm{S}$ mivel ezek a fontos elméletek értelemszerúen nem voltak ismertek idehaza, Talyigás Kati sorozatszerkesztő társammal belekezdtünk egy hétkötetesre tervezett könyvsorozat kiadásába „A szociális munka elmélete és gyakorlata" címen, természetesen kiváló szerkesztő kollégákkal együttmüködve, mint például Kozma Judit, Gosztonyi Géza, Szilvási Léna, Németh László, Kövér Ágnes. 6 kötetig jutottunk. Úgy tudom, hogy még mindig használatban vannak az alapelméleteket bemutató, az egyéni, csoport- és közösségi munkát taglaló, illetve a szociális munka oktatását és a szociális adminisztrációt elemző kötetek - bár megérett az idő, hogy az eltelt 20 év alatt klasszikussá érett cikkekkel frissítsük fel a köteteket. Ez már azonban a következő generáció feladata lesz!

A „Soproni normában” eltervezett szociálismunkás-képzés viszont meg is valósult mind a három tervezett szinten: középfokon, föiskolai és egyetemi szinten. A rendszer nem volt tökéletes, de azt hiszem, maradandónak bizonyult, át lehetett probléma nélkül alakítani négyszintüvé a bolognai rendszer bevezetésekor - középfok, BA, MA, PhD.

A mai nehézségeket is csak úgy lehet megérteni, ha egy komoly társadalomtörténeti elemzésen keresztül vizsgáljuk a szociális munkát, az arra ható politikai és társadalompolitikai hatásokat, a szociális problémák megítélésének társadalmi hátterét, a kliensek problémáinak inkább együttmunkálkodáson vagy inkább büntetésen alapuló megoldási javaslatait stb. Ez azonban messze meghaladja a mostani interjú kereteit, az óra befejezödött. Köszönöm, hogy mindezt elmondhattam. ${ }^{4}$

\footnotetext{
${ }^{4} \mathrm{~S}$ a nem említett sok-sok életeseményt, kollégát, barátot, megvalósult és meg nem valósult tervet, sok hazai és külföldi oktatási és civil tapasztalatot, szakmai kutatást és történetet, s még oly’ sok mindent, amit egy hosszú élet ajándékba adott, egyszer talán még megírom.
} 